\title{
Oxidative stress, perturbed calcium homeostasis, and immune dysfunction in Alzheimer's disease
}

\author{
Mark P Mattson \\ Laboratory of Neurosciences, National Institute on Aging Gerontology Research Center, Baltimore, Maryland, USA, \\ and Department of Neuroscience, Johns Hopkins University School of Medicine, Baltimore, Maryland, USA
}

\begin{abstract}
Although Alzheimer's disease (AD) may not involve a transmissible agent, it does involve a pathogenic process similar to that of transmissible prion disorders (both involve a protein that adopts an abnormal pathogenic conformation in which it self-aggregates, forming amyloid deposits in and surrounding neurons) and viral dementias such as human immunodeficiency virus (HIV) encephalitis. The clinical presentation of patients with AD is dominated by cognitive deficits and emotional disturbances that result from dysfunction and degeneration of neurons in the limbic system and cerebral cortex. The pathogenic process in the brain involves deposition of insoluble aggregates of amyloid $\beta$-peptide, oxidative stress and calcium dysregulation in neurons, and activation of inflammatory cytokine cascades involving microglia. However, AD patients also exhibit alterations in immune function. Studies of lymphocytes and lymphoblast cell lines from AD patients and age-matched normal control patients have documented alterations in cytokine and calcium signaling and increased levels of oxidative stress in immune cells from the AD patients. Studies of the pathogenic actions of mutations in presenilins and amyloid precursor protein that cause early-onset familial AD have established central roles for perturbed cellular calcium homeostasis and oxidative stress in the neurodegenerative process. Presenilin and amyloid precursor protein (APP) mutations also increase oxidative stress and perturb calcium signaling in lymphocytes in ways that alter their production of cytokines that are critical for proper immune responses. Immune dysfunction occurs prior to clinical symptoms in mouse models of $\mathrm{AD}$, and brain cytokine responses to immune challenge are altered in presenilin mutant mice, suggesting a causal role for altered immune function in the disease process. Interestingly, immunization of AD mice with amyloid $\beta$-peptide can stimulate the immune system to remove amyloid from the brain and can ameliorate memory deficits, suggesting that it may be possible to prevent AD by bolstering immune function. Journal of NeuroVirology (2002) 8, 539-550.
\end{abstract}

Keywords: Alzheimer's disease; apoptosis; inositol trisphosphate; lymphocytes; ryanodine

\section{Introduction}

Several observations suggest that a better understanding of the pathogenesis of $\mathrm{AD}$ may reveal mechanisms shared with transmissible neurodegen-

Address correspondence to Mark P Mattson, Laboratory of Neurosciences, National Institute on Aging, 5600 Nathan Shock Drive,

Baltimore, MD 21224, USA. E-mail: mattsonm@grc.nia.nih.gov

This article is not subject to U.S. copyright laws.

Received 23 January 2002; revised 27 March 2002; accepted 26 April 2002. erative disorders caused by viruses and prions. The infectious agents of prion disorders were initially thought to be unconventional viruses, but are now believed to involve only abnormal proteins that adopt pathogenic conformations in which they self-aggregate, forming amyloid deposits in and surrounding cells (Prusiner, 2001). It was recognized several decades ago that Alzheimer's disease (AD) shares features of prion disorders (Masters and Beyreuther, 1988), although AD appears not to be transmissible (but see Baker et al, 1994, for evidence of transmissibility). $\mathrm{AD}$ is characterized 


\begin{tabular}{|c|c|c|}
\hline HIV Encephalitis & Prion Disorders & Alzheimer's Disease \\
\hline $\begin{array}{l}\text { Infection } \\
\text { Viral replication } \\
\text { Toxic protein (Tat, gp120) } \\
\text { Perturbed ion homeostasis } \\
\text { Microglial activation } \\
\text { Oxyradical production } \\
\text { Apoptosis - excitotoxicity }\end{array}$ & $\begin{array}{l}\text { Infection } \\
\text { Protein aggregation } \\
\text { Oxidative stress } \\
\text { Perturbed ion homeostasis } \\
\text { Microglial activation } \\
\text { Apoptosis - excitotoxicity }\end{array}$ & $\begin{array}{l}\text { Amyloid production } \\
\text { Protein aggregation } \\
\text { Oxidative stress } \\
\text { Perturbed ion homeostasis } \\
\text { Microglial activation } \\
\text { Apoptosis - excitotoxicity }\end{array}$ \\
\hline
\end{tabular}

Figure 1 Comparison of pathogenic cascades that result in neuronal degeneration in virus- and prion-based neurodegenerative disorders, and in Alzheimer's disease. All three cascades involve the action of toxic protein that induces oxidative stress and disrupts cellular calcium homeostasis in neurons.

by progressive cognitive dysfunction and emotional disturbances caused by dysfunction and degeneration of neurons in the limbic system and cerebral cortex (Galasko et al, 1994). Transmissible neurodegenerative disorders share similarities with $\mathrm{AD}$. For example, although human immunodeficiency virus (HIV) encephalitis seems to impact primarily the basal ganglia, it also adversely affects neurons in the overlying cerebral cortex and hippocampus (Nath, 1999; Rausch and Davis, 2001). In addition, prion disorders such as Creutzfeld-Jacob disease (CruzSanchez et al, 1988) are also characterized by degeneration of neurons in brain regions involved in learning, memory, and emotional behaviors. AD, HIV encephalitis, and prion disorders each involve damage to neurons caused by one or more toxic proteins, amyloid $\beta$-peptide (A $\beta$ ) in AD (Mattson, 1997), Tat and gp120 in HIV encephalitis (Kruman et al, 1998; Lipton, 1998), and the prion protein in CreutzfeldJacob disease (Prusiner, 2001) (Figure 1). Moreover, the mechanism of neurotoxicity in each case involves oxidative stress and disruption of neuronal calcium homeostasis, resulting in excitotoxicity and apoptosis (Mattson, 2000; Fazakerley and Allsopp, 2001; Giese and Kretzschmar, 2001).

A pivotal event in the pathogenesis of $\mathrm{AD}$ is the accumulation of insoluble deposits of $\mathrm{A} \beta$ in the form of plaques; it is thought that $\mathrm{A} \beta$ deposits damage and kill neurons by a mechanism involving oxidative stress and a disruption of cellular calcium homeostasis (Mattson, 1997) (Figure 2). A $\beta$ appears to induce oxidative stress and perturbing neuronal ion homeostasis by promoting membrane lipid peroxidation, which can impair the function of ion-motive ATPases and glucose and glutamate transport proteins. These effects of $\mathrm{A} \beta$ may result in the characteristic cytoskeletal pathology of neurons in $\mathrm{AD}$, called neurofibrillary tangles, which consist of hyperphosphorylation and aggregation of the microtubuleassociated protein tau.

Both genetic and environmental factors can influence the risk and course of AD. Genetic mutations can cause $\mathrm{AD}$, and numerous families that harbor $\mathrm{AD}$ genes that are inherited in an autosomal dominant manner have been identified (Hardy, 1997). Many such familial AD (FAD) cases, which have a very early age of disease onset (30s, 40s, and 50s), have been shown to be caused by mutations in one of three genes: the $\beta$-amyloid precursor protein (APP; located on chromosome 21), presenilin-1 (PS1; chromosome 14), and presenilin-2 (PS2; chromosome 1). APP is the source of $\mathrm{A} \beta$; it is a large integral membrane protein with a single membrane-spanning domain and a large extracellular region that possesses several biologically active domains. APP is a substrate for three different enzyme activities: $\alpha$-secretase cleaves APP in the middle of the $\mathrm{A} \beta$ sequence at the cell surface and thereby releases an extracellular portion of APP ( $\mathrm{sAPP} \alpha) ; \beta$-secretase (BACE) cleaves APP at the N-terminus of $\mathrm{A} \beta$, producing a membraneassociated $\mathrm{C}$-terminal fragment that contains intact $\mathrm{A} \beta ; \gamma$-secretase cleaves APP at the C-terminus of $\mathrm{A} \beta$, liberating full-length $\mathrm{A} \beta$ ( $\mathrm{A} \beta 40$ or $\mathrm{A} \beta 42)$ from cells (Hardy, 1997; Mattson, 1997; Vassar et al, 1999). FAD mutations in APP are located at either end, or in the middle, of the $\mathrm{A} \beta$ sequence and alter the proteolytic processing of APP in a manner that increases production of $\mathrm{A} \beta$ (particularly $\mathrm{A} \beta 42$ ) and decreases production of sAPP $\alpha$. FAD mutations in PS1 and PS2 also increase production of $\mathrm{A} \beta 42$ (Hardy, 1997).

PS1 is a $46-\mathrm{kDa}$ integral membrane protein with 8 transmembrane domains; the amino and carboxy termini, and a large hydrophilic loop domain are located on the cytoplasmic side of the membrane. In addition to full-length PS1, many cells also contain 26-kDa N-terminal and 17-kDa C-terminal PS1 cleavage products. PS1 is localized primarily in the endoplasmic reticulum (ER) and is widely expressed in the nervous and immune systems, and in many other tissues. More than 70 different mutations in PS1 have been linked to familial early-onset $\mathrm{AD}$, most of which are missense mutations that result in a single amino acid change in the PS1 protein. The mutations tend to be clustered adjacent to transmembrane domain 2 and in the hydrophilic loop region. Because PS2 mutations are a more rare cause of FAD, PS2 has not been studied as intensively as PS1.

Environmental risk factors for AD have emerged in recent years. Epidemiological studies have revealed associations between a low level of education (Evans et al, 1997), traumatic head injury (Lye and Shors, 2000), and a high calorie intake (Mayeux et al, 1999) and increased risk of AD. Emerging data from studies of animal models of $\mathrm{AD}$ and related neurodegenerative disorders suggest that dietary restriction and "enriched environments" can protect neurons and promote synaptic plasticity by up-regulating the expression of neurotrophic factors, such as brainderived neurotrophic factor, neurotrophin-3, and protein chaperones, such as heat-shock protein-70 and glucose-regulated protein-78 (Bruce-Keller et al, 1999; Duan and Mattson, 1999; Yu and Mattson, 1999; Lee et al, 2000, 2002). 


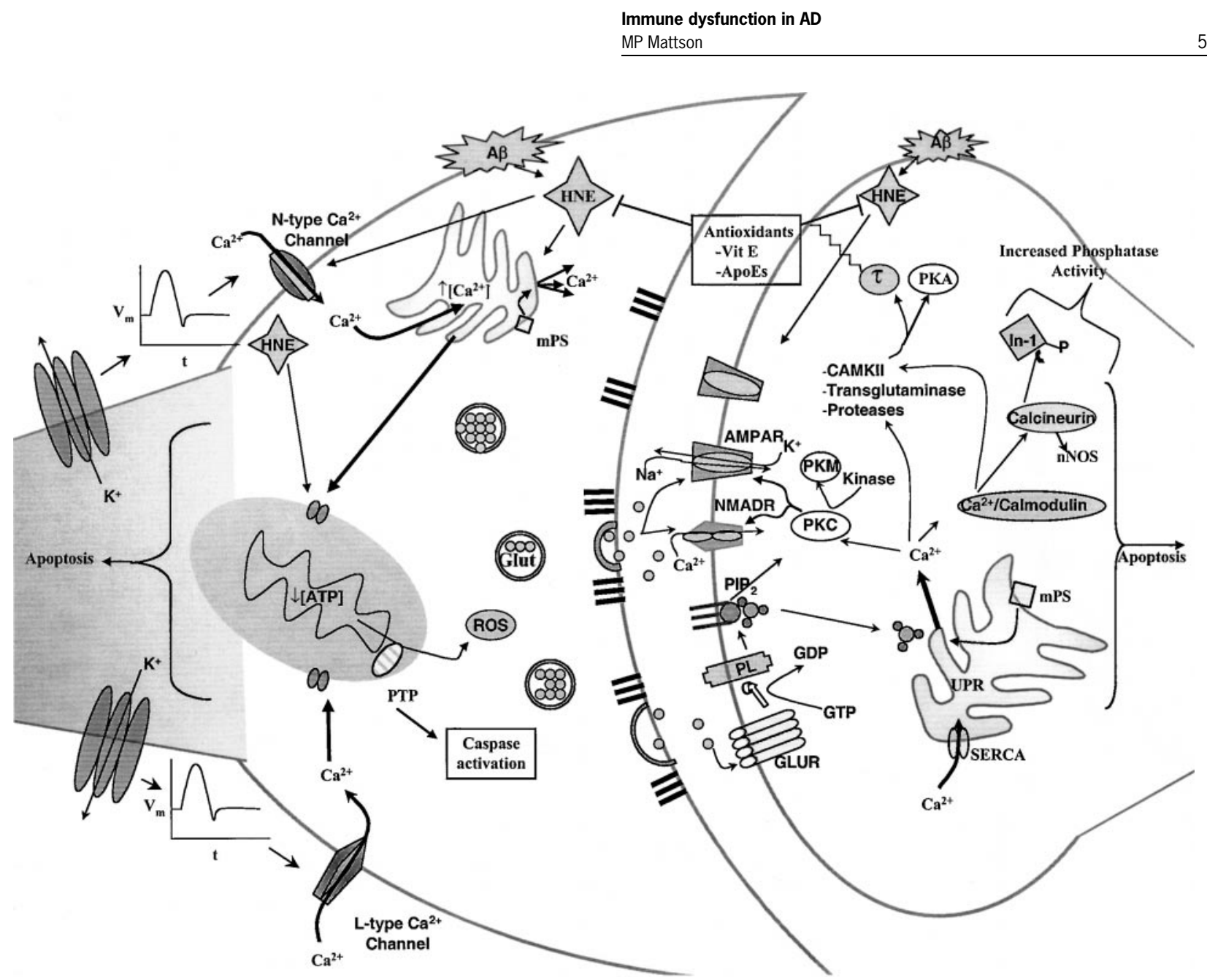

Figure 2 Mechanisms involved in the regulation of calcium homeostasis in neurons and potential alterations in Alzheimer's disease. $\mathrm{A} \beta$, amyloid $\beta$-peptide; AMPAR, alpha-amino-3-hydroxy-5-methyl-4-isoxazolepropionic acid receptor; CAMK, calcium-calmodulindependent protein kinase; GLUR, metabotropic glutamate receptor; HNE, 4-hydroxynonenal; mPS, mutant presenilin; NMDAR, $N$-methylD-aspartate receptor; NOS, nitric oxide synthase; PKA, cyclic AMP-dependent protein kinase; PKC, protein kinase C; PKM, protein kinase, membrane-associated; PL, phospholipase; PTP, permeability transition pore; ROS, reactive oxygen species; SERCA, sarco (smooth) endoplasmic reticulum calcium ATPase.

\section{Evidence for altered immune function in AD}

Histological, biochemical, and molecular analyses of postmortem brain tissue from $\mathrm{AD}$ patients have revealed numerous changes, suggesting the involvement of inflammatory processes in the pathogenesis of the disease. The roles of microglia and inflammatory processes in $\mathrm{AD}$ has been a subject of intense interest, because of the potential ability of antiinflammatory drugs to slow the neurodegenerative process in symptomatic patients, as well as their potential use in prophylaxis. The findings have recently been reviewed in considerable detail (McGeer and McGeer, 1999; Lukiw and Bazan, 2000), and I will therefore briefly summarize a few of the salient aspects of the brain immune response in AD. Activated microglia congregate in and surrounding amyloid plaques where they may produce cytokines, reactive oxygen species, and excitotoxins that can damage and kill neurons. Proinflammatory cytokines that are increased in vulnerable brain regions of $\mathrm{AD}$ patients include tumor necrosis factor (TNF), interleukin-1 (IL-1), and interleukin-6 (IL-6) (Mrak and Griffin, 2001). Activated microglia also produce nitric oxide and superoxide anion radical, which may damage neurons (Kim and Ko, 1998). However, the role of microglia in $\mathrm{AD}$ is likely very complex, because their products can either prevent or promote neuronal degeneration depending upon a variety of factors. For example, TNF can protect neurons against death induced by $\mathrm{A} \beta$ and oxidative insults (Barger et al, 1995; Mattson et al, 1997), but may indirectly promote neuronal degeneration by enhancing microglial activation. In addition, the role of activated microglia associated with amyloid plaques is unclear. Although some investigators have suggested that the activated microglia play a key role in the neurodegenerative process, recent findings suggest that the microglia may actually remove and thereby detoxify the amyloid (DiCarlo et al, 2001).

The complement cascade and pentraxins are activated in association with amyloid deposits and 
degenerating neurons in $\mathrm{AD}$ brain tissue, and studies of cultured brain cells and APP mutant transgenic mice suggest that $\mathrm{A} \beta$ may induce this cytotoxic cascade. Indeed, it was reported that $\mathrm{A} \beta$ can activate complement (Rogers et al, 1992) and that C-reactive protein and amyloid $\mathrm{P}$ are produced by neurons and are up-regulated in neuritic plaques (Yasojima et al, 2000). A $\beta$ binds to the collagen tail of $\mathrm{C} 1 \mathrm{q}$ and this binding may nucleate the formation of $\mathrm{A} \beta$ fibrils (Webster et al, 1995). This suggests that drugs that target $\mathrm{C} 1 \mathrm{q}$ might be effective in preventing the neurodegenerative process in $\mathrm{AD}$ patients. Inhibition of C5 convertase or other steps in the complement cascade would also prevent formation of the membrane attack complex.

Abnormalities in the peripheral immune systems of $\mathrm{AD}$ patients have also been reported in several studies. Patients with AD exhibit increased plasma levels of IL-1, IL-6, and alpha-1-antichymotrypsin consistent with a chronic inflammatory state (Licastro et al, 2000). T cells from AD patients exhibited increased IL-6 binding and decreased interferongamma binding compared to T cells from control patients (Bongioanni et al, 1997, 1998). Analysis of blood mononuclear cells from $\mathrm{AD}$ and control patients revealed a number of changes in antigens and cytokines in cells from $\mathrm{AD}$ patients, including significant increases in CD4, CD25, and CD28; significant increases in lipopolysaccharide (LPS)-induced TNF, IL-6, and IL-10 production; and significant decreases in CD7 and CD8 (Lombardi et al, 1999). The study of Lombardi et al (1999) also revealed increased apoptosis of lymphocytes from the AD patients. In another study, levels of immune-associated antigens (human leukocyte antigen [HLA]-DR, CD4, CD8, IL-2 receptor) were measured in lymphocytes from patients that were classified as having either mild or moderate probable $\mathrm{AD}$. The only change seen in lymphocytes from the mild group was an increase in HLADR, whereas lymphocytes from the moderate group exhibited increased levels of HLA-DR and CD4 and a decrease in CD8 levels (Shalit et al, 1995). More dramatic alterations were observed when the lymphocytes were challenged with the mitogen phytohemagglutinin (PHA), namely, a marked reduction in IL-2 receptor levels, an increase in IL-2 secretion, and a decreased proliferative response. Plasma levels of TNF are increased in association with dementia in centenarians (Bruunsgaard et al, 1999). However, it should be noted that other studies have yielded negative data concerning alterations in cytokine levels in AD. For example, in a longitudinal study of blood and cerebrospinal fluid levels of TNF, IL-1beta, IL-6, and alpha-1-antichymotrypsin, no differences were found between $\mathrm{AD}$ and control patients and there were no correlations of any of these cytokines with severity of dementia in the $\mathrm{AD}$ patients (Lanzrein et al, 1998).

Studies of patients with familial AD and of animal models of AD suggest that peripheral immune dysfunction may occur early in the disease, perhaps even prior to pathogenic changes in the brain. Lymphoblasts from AD patients with PS1 mutations and APP mutations exhibit decreased levels of glutathione compared to lymphoblasts from agematched control patients (Cecchi et al, 1999). Lymphocytes from PS1 mutant mice also exhibit hypersensitivity to death, which is associated with increased production of oxyradicals and altered calcium homeostasis (Eckert et al, 2001). It is known that oxidative stress can impair transmembrane and nuclear signal transduction in lymphocytes, resulting in reduced anti-CD3-induced IL-2 production and phosphorylation, and decreased nuclear factor of activated $\mathrm{T}$ cells (NFAT) and nuclear factor (NF) $-\kappa \mathrm{B}$ DNA binding (Flescher et al, 1994). Finally, recent findings suggest that polymorphisms in genes involved in immune cell function may affect risk of AD. For example, the $\mathrm{C}$ allele of the IL-6 genotype was associated with decreased risk of $\mathrm{AD}$ (Papassotiropoulos et al, 1999).

\section{Increased oxidative stress and altered calcium signaling in the pathogenic actions of APP and PS1 mutations}

The evidence that oxidative stress and alterations in neuronal calcium homeostasis play major roles in the dysfunction and death of neurons in $\mathrm{AD}$ has been reviewed previously (Mattson, 1997). Calcium signaling in both neurons and lymphocytes plays central roles in the regulation of the functions of these complex cells (Berridge et al, 2000; Lewis, 2001). The large concentration gradient across the plasma membrane, approximately $2 \mathrm{mM}$ outside the cell and approximately $100 \mathrm{nM}$ inside the cell, is maintained largely by removal of $\mathrm{Ca}^{2+}$ from the cytoplasm by plasma membrane and ER $\mathrm{Ca}^{2+}$-ATPases. $\mathrm{Ca}^{2+}$ influx can occur via opening of plasma membrane voltage-dependent and ligand-gated $\mathrm{Ca}^{2+}$ channels. In addition, activation of receptors coupled via GTP-binding proteins to phospholipase-C and production of inositol 1,4,5-trisphosphate $\left(\mathrm{IP}_{3}\right)$ results in release of $\mathrm{Ca}^{2+}$ from ER stores. The $\mathrm{Ca}^{2+}$ concentration gradient across the ER membrane is maintained by the sarco(endo)plasmic reticulum calcium ATPase (SERCA). ER contains two types of $\mathrm{Ca}^{2+}$ channels that regulate calcium release, the inositol 1,4,5trisphosphate receptor $\left(\mathrm{IP}_{3} \mathrm{R}\right)$ and the ryanodine receptor (RYR). $\mathrm{Ca}^{2+}$ release and uptake in the ER is also modualted by several different proteins, including the FK506-binding protein (Brillantes et al, 1994), calcineurin (Cameron et al, 1996), calmodulin (Yamada et al, 1995), the cytoskeletal protein ankyrin (Bourguignon and Jin, 1995), and sorcin (Pickel et al, 1997).

Considerable evidence supports a cause-effect relationship between altered calcium homeostasis and neuronal dysfunction and death in $\mathrm{AD}$. 
Overactivation of glutamate receptors, and other conditions that result in a sustained elevation of intracellular $\mathrm{Ca}^{2+}$ levels, can induce alterations in the neuronal cytoskeleton similar to those seen in neurofibrillary tangles (Mattson, 1990). By increasing A $\beta$ production and decreasing $\operatorname{sAPP} \alpha$ production, alterations in APP processing that occur in AD, can disrupt cellular calcium homeostasis and render neurons vulnerable to degeneration and death. Aggregating $\mathrm{A} \beta$ associates with the plasma membrane where it induces oxidative stress and membrane lipid peroxidation, resulting in the impairment the function of membrane transporters, including ion-motive ATPases $\left(\mathrm{Na}^{+} / \mathrm{K}^{+}\right.$-ATPase and $\mathrm{Ca}^{2+}$-ATPase), glucose transporters, and glutamate transporters (Mark et al, 1995, 1997; Blanc et al, 1998). A $\beta$ may generate reactive oxygen species, including hydrogen peroxide and hydroxyl radical, via a chemical reaction involving interactions with iron and/or copper and oxidation of methionine residue 35 (Atwood et al, 2000; Butterfield et al, 2001). Impairment of the membrane transporters results in membrane depolarization, energy (ATP) depletion, and overactivation of glutamate receptors, which can result in excitotoxicity and apoptosis. The decreased production of sAPP $\alpha$ that occurs in AD may also contribute to perturbed cellular calcium homeostasis, because sAPP $\alpha$ has been shown to activate a signaling pathway that hyperpolarizes the plasma membrane and protects neurons against death induced by glutamate and $\mathrm{A} \beta$ (Mattson et al, 1993). On the other hand, it was recently reported that $\mathrm{sAPP} \alpha$ can stimulate the release of glutamate from microglia, which could promote excitotoxic neuronal injury (Barger and Basile, 2001). Thus, the direct actions of sAPP $\alpha$ on neurons may be beneficial, whereas its actions on microglia may be detrimental.

Perturbed APP processing can also alter gene expression in ways that may disrupt cellular calcium homeostasis. A $\beta$ can induce activation of proapoptotic gene expression, including immediate-early genes, proapoptotic Bcl-2 family members, and the tumor suppressor protein p53 (Culmsee et al, 2001). sAPP $\alpha$, on the other hand, can induce activation of the cell survival-promoting transcription factor NF$\kappa \mathrm{B}$ (Guo et al, 1998b), which can stabilize cellular calcium homeostasis by modulating the expression of genes that encode the $\mathrm{Ca}^{2+}$-binding protein calbindin, glutamate receptor subunits, and antiapoptotic Bcl-2 family members.

The discovery that PS1 mutations can cause AD has led to compelling evidence for a primary role for perturbed cellular calcium signaling in the pathogenesis of AD. Studies of cultured neuronal cell lines, primary neurons, and transgenic and knockin mice have shown that PS1 and PS2 mutations increase the vulnerability of cells to apoptosis and excitotoxicity (Guo et al, 1996, 1997, 1999). Cells expressing PS1 mutations are more vulnerable to apoptosis induced by trophic factor withdrawal, exposure to $\mathrm{A} \beta$, and other insults. The cell death-promoting effect of mutant PS1 involves an abnormality in the regulation of calcium homeostasis. $\mathrm{Ca}^{2+}$ responses to glutamate, to the muscarinic agonist carbachol, and to bradykinin are greatly enhanced in neural cells overexpressing mutant PS1 (Guo et al, 1996, 1997, 1999). The enhanced $\mathrm{Ca}^{2+}$ responses are observed in cells incubated in the absence of extracellular $\mathrm{Ca}^{2+}$, indicating that enhanced $\mathrm{Ca}^{2+}$ release from internal stores is the primary abnormality caused by the PS1 mutations. The enhanced release of $\mathrm{Ca}^{2+}$ from ER stores caused by PS1 mutations can result in cytosolic calcium overload and increased vulnerability of cells to being killed by glutamate and other insults. Intracellular calcium chelators, overexpression of $\mathrm{Ca}^{2+}$ binding proteins, dantrolene (an inhibitor of RYR), and xestospongin (an inhibitor of $\mathrm{IP}_{3} \mathrm{R}$ ) can protect cells against the death-promoting actions of PS1 mutations (Guo et al, 1997, 1998a; Chan et al, 2000). Calcium imaging and electrophysiological analyses suggest that an overfilling of ER $\mathrm{Ca}^{2+}$ stores occurs in cells expressing mutant presenilins, resulting in a greater $\mathrm{Ca}^{2+}$ response to various stimuli that promote $\mathrm{Ca}^{2+}$ release (Guo et al, 1996; Chan et al, 2000; Leissring et al, 2000a). Aberrant ER $\mathrm{Ca}^{2+}$ signaling caused by presenilin mutations may, in turn, alter capacitative $\mathrm{Ca}^{2+}$ entry through voltage-dependent channels in the plasma membrane (Leissring et al, 2000b; Yoo et al, 2000).

Although the mechanism whereby PS mutations enhance $\mathrm{Ca}^{2+}$ release is not established, recent findings suggest that PS1 can interact either directly or indirectly with $\mathrm{RYR}$ and $\mathrm{IP}_{3} \mathrm{R}$ (Chan et al, 2000). PS1 and PS2 were reported to interact with a novel $\mathrm{Ca}^{2+}$-binding protein called calsenilin, an interaction that may alter proteolytic processing of the presenilins (Buxbaum et al, 1998). Calsenilin can suppress the enhancement of $\mathrm{Ca}^{2+}$ release caused by presenilin mutations (Leissring et al, 2000b). A RYRassociated protein called sorcin was reported to interact with PS2, an interaction that is enhanced when intracellular $\mathrm{Ca}^{2+}$ levels are increased (Pack-Chung et al, 2000). In addition, the $\mathrm{Ca}^{2}$-binding protein calmyrin interacts with PS2 and might modulate PS2 functions in the ER membrane (Stabler et al, 1999). Finally, PS1 and PS2 can interact with the $\mathrm{Ca}^{2}$ dependent protease $\mathrm{m}$-calpain and inhibit its proteolytic activity; AD-linked mutations in presenilin reduce their ability to inhibit m-calpain, suggesting that the death-promoting effect of the mutations might be due, in part, to enhanced $\mathrm{Ca}^{2+}$-mediated proteolysis (Maruyama et al, 2000).

The consequences of perturbed cellular calcium homeostasis caused by PS1 mutations are likely to be many, given the multitude of roles for calcium in synaptic plasticity, gene expression, and cell survival. For example, PS1 mutations result in aberrant regulation of $\mathrm{NF}-\kappa \mathrm{B}$, a transcription factor that regulates neuronal survival and plasticity (Guo et al, 1998b). Synapses are likely to be the regions 
of neurons where the adverse effects of presenilin mutations are first exerted. $\mathrm{ER} \mathrm{Ca}^{2+}$ release and $\mathrm{Ca}^{2+}$ influx through plasma membrane channels play important roles in regulating synaptic functions, including learning and memory (Chittajallu et al, 1998). Analyses of synaptic transmission in hippocampal slices from PS1 mutant mice have documented alterations consistent with enhanced $\mathrm{Ca}^{2+}$ release or influx (Parent et al, 1999; Barrow et al, 2000). In addition, cortical synaptosomes from PS1 mutant mice exhibit enhanced calcium responses to membrane depolarization, as well as increased cytoplasmic $\mathrm{Ca}^{2+}$ levels following exposure to $\mathrm{A} \beta$ and mitochondrial toxins (Begley et al, 1999). Abnormal synaptic calcium homeostasis is therefore central to the pathogenic mechanism of presenilin mutations.

\section{APP, presenilins, and calcium signaling defects in lymphocytes}

Remarkably, many of the findings concerning the actions of $\mathrm{A} \beta$ and presenilin mutations in neurons described above, have been extended to studies of lymphocytes. Levels of oxidative stress are increased in lymphocytes from AD patients compared to lymphocytes from age-matched control patients (Mecocci et al, 1998; Cecchi et al, 1999; Morocz et al, 2002). Exposure of lymphocytes and erythrocytes to $\mathrm{A} \beta$ results in oxidative stress and disrupts cellular ion homeostasis (Eckert et al, 1996; Mattson et al, 1997b).

Calcium signaling plays major roles in regulating responses of lymphocytes to a variety of signals (Guse, 1998). Antigen-induced activation of cell surface receptors in $\mathrm{B}$ and $\mathrm{T}$ lymphocytes triggers calcium release from ER stores (Figure 3). $\mathrm{IP}_{3} \mathrm{R}$ play a particularly important in lymphocyte signaling because blockade of expression of the type $3 \mathrm{IP}_{3} \mathrm{R}$ prevents apoptosis of lymphocytes (Kahn et al, 1996). Abnormalities in lymphocyte calcium signaling have been documented in studies of AD patients, including patients with presenilin mutations. Peak calcium responses to anti-CD3 monoclonal antibody were decreased, whereas calcium responses to PHA were unchanged, in CD4+ lymphocytes from AD patients with PS1 mutations, sporadic AD patients, and older Down syndrome patients compared to lymphocytes from age-matched control patients (Grossmann et al, 1993). Activity of $\mathrm{Ca}^{2+}$-dependent proteases was reported to be increased in lymphocytes from AD patients (Karlsson et al, 1995). In addition, PHAinduced lymphocyte proliferation was reduced in elderly subjects compared to young persons, whereas $\mathrm{AD}$ patients tended to have a significantly higher proliferative response than age-matched controls (Song et al, 1999). The latter results might be explained by alterations in calcium signaling because the calcium response of lymphocytes to phytohemagglutinin is decreased during normal aging and increased in $\mathrm{AD}$ patients (Sulger et al, 1999). Lymphocytes from late- onset $\mathrm{AD}$ patients exhibit higher basal cytosolic $\mathrm{Ca}^{2+}$ concentrations than controls, and a larger calcium response to anti-immunoglobulin M (IgM).

An intriguing signaling pathway that regulates the fate of developing neural and immune cells involves a transmembrane receptor protein called Notch. When activated by cell-associated ligands, Notch is proteolytically processed in a manner that releases an intracellular C-terminal fragment, which then translocates to the nucleus where it may regulate gene expression (Artavanis-Tsakonis et al, 1995). Interestingly, presenilins play critical roles in Notch signaling. As evidence, the phenotype of PS1-null mice is essentially identical to that of Notch-1 knockout mice (Conlon et al, 1995; Shen et al, 1997; Handler et al, 2000), and the cellular expression of PS1 and Notch in the developing rodent nervous system are very similar, being high during neurogenesis and decreasing as the embryo develops (Williams et al, 1995). In addition, the level of Hes5, a gene induced by activation of the Notch signaling pathway, is decreased in the ventricular zone of PS1-null mice, whereas levels of the Notch1 ligand are elevated (Handler et al, 2000). Overexpression of Notch can protect against apoptosis induced by T-cell receptor cross-linking and exposure to glucocorticoids (Osborne and Miele, 1999). Studies of Drosophila indicate that PS1 may not be necessary for constitutive processing of Notch, but is necessary for ligandinduced transmembrane cleavage of Notch (Struhl and Greenwald, 2001), suggesting that a highly conserved function of PS1 is to facilitate Notch signaling and thereby regulate cell fate decisions. The specific molecular interactions whereby presenilins regulate cleavage of APP and Notch remain to be determined, although the available data suggest that presenilins are either involved in the enzymatic activities or in trafficking of Notch and APP to sites where they are proteolytically processed.

Increasing evidence suggests that there are widespread alterations in cell metabolism and signaling in immune cells of AD patients, with abnormalities in the immune system being prominent. For example, there is enhanced IgM-induced intracellular acidification associated with a loss of effectiveness of a $\mathrm{Ca}^{2+}$ /calmodulin-dependent mechanism in controlling the activity of the $\mathrm{Na}^{+} / \mathrm{H}^{+}$exchanger, with a decreased intracellular $\mathrm{H}^{+}$-buffering capacity (Ibarreta et al, 1998); an increased cytotoxic response by natural killer cells to interleukin-2 and a smaller suppression of natural killer cytotoxicity after cortisol administration (Solerte et al, 1998); and increased levels of p55 and p75 TNF receptors in T lymphocytes (Bongionanni et al, 1997). Recent studies suggest that presenilin mutations can alter immune responses in lymphocytes. The proteolytic processing of PS1 is altered in lymphocytes from patients with PS1 mutations such that more full-length PS1 is produced (Takahashi et al, 1999). In another study, a 


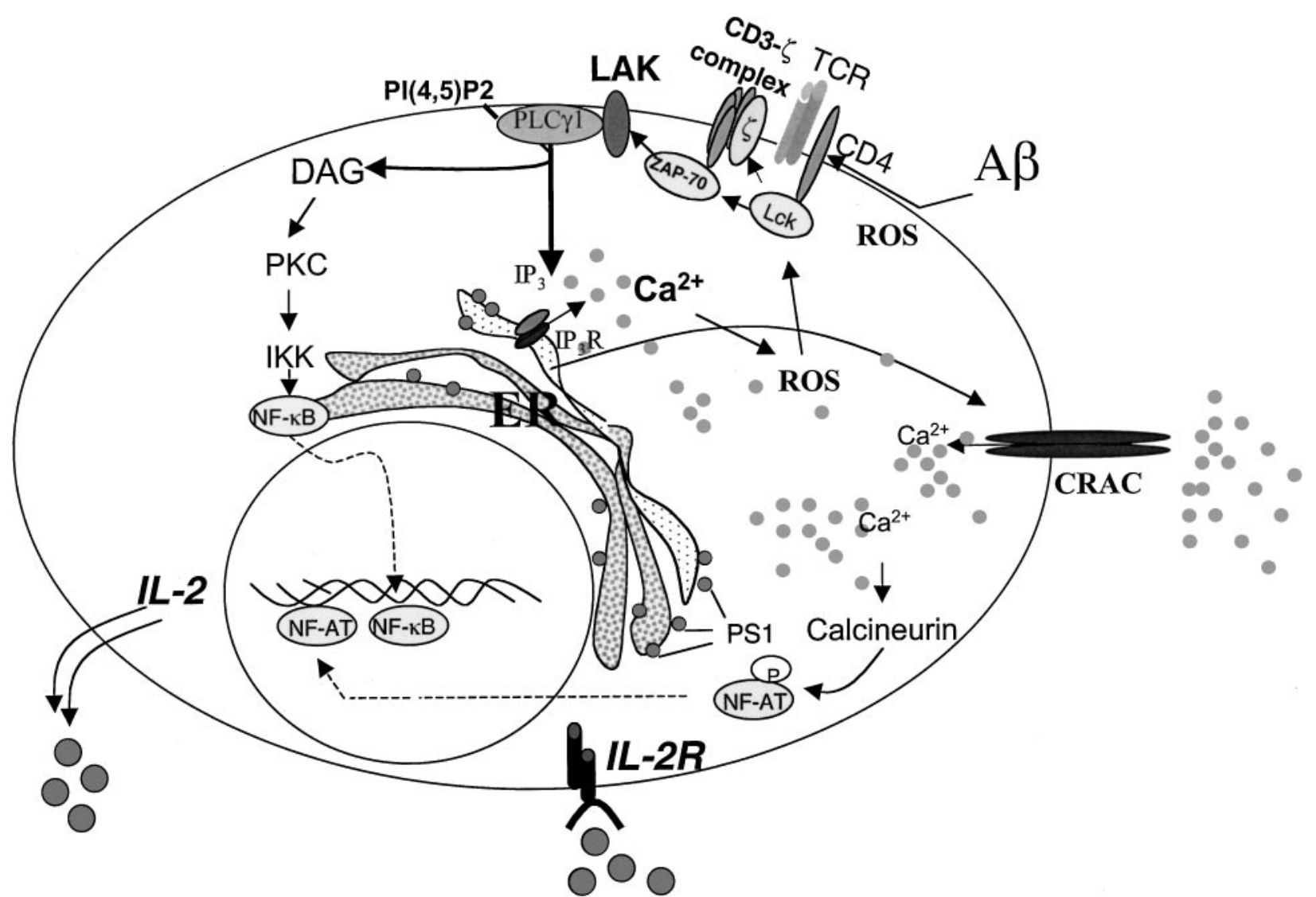

Figure 3 Lymphocyte signaling pathways and their possible compromise in Alzheimer's disease T cell receptor (TCR) engagement results in the recruitment of CD4-associated tyrosine kinase Lck and phosphorylation of the immunoreceptor tyrosine-based activation motifs (ITAMs) of the signal transducing subunits $\operatorname{CD} 3 \gamma, \delta, \varepsilon$, and $\zeta$ (CD3- $\zeta$ complex). The tyrosine kinase ZAP70 then associates with phosphorylated ITAMs and is itself phosphorylated and activated by Lck. LAK (linker for activation of T cells) is phosphorylated by ZAP-70 and is able to recruit PLC $\gamma 1$ to the plasma membrane where it hydrolyzes PI $(4,5) \mathrm{P}_{2}$ to inositol 1,4,5-triphosphate $\left(\mathrm{IP}_{3}\right)$ and diacylglycerol (DAG). DAG activates PKC, which phosphorylates $\mathrm{I} \kappa \mathrm{B}$ kinase (IKK), resulting in activation of the transcription factor NF- $\kappa \mathrm{B}$, whereas $\mathrm{IP}_{3}$ induces calcium release from the endoplasmic reticulum (ER). Depletion of the ER calcium pool triggers capacitative calcium entry, which culminates in a sustained elevation of cytoplasmic calcium levels. Calcium activates calcineurin, which dephosphorylates and thereby activates the transcription factor NF-AT (nuclear factor of activated T cells), which is critical for T-cell activation and interleukin-2 (IL-2) production. Levels of oxidative stress may be increased in $\mathrm{AD}$ as the result of exposure to $\mathrm{A} \beta$ or perturbed calcium homeostasis. In familial AD, altered ER calcium signaling caused by PS1 mutations may therefore have a negative impact on the function of these lymphocytes, and PS1 mutations may also affect the initial phases of T-cell activation by down-regulating the TCR signaling pathway. Modified from Mattson et al (2001).

functional selection strategy for genes involved in T-cell apoptosis was used to identify a gene encoding a truncated PS2 as a protein that antagonizes the apoptotic action of PS2 (D'Adamio et al, 1997). The latter study further showed that PS2 enhances apoptosis in T cells.

In order to more directly determine the impact of presenilin mutations on immune function, we and others have performed studies of PS1 mutant mice. Eckert and colleagues (2001) studied lymphocytes from transgenic mice overexpressing the M146L mutation under the control of the 3-hydroxy3-methylglutaryl coenzyme A (HMG-CoA) reductase promoter. They found that lymphocytes from the PS1 mutant mice exhibited increased spontaneous apoptosis and increased vulnerability to deathinduced by hydrogen peroxide compared to lympho- cytes from transgenic mice overexpressing wild-type PS1 or lymphocytes from nontransgenic mice. Moreover, lymphocytes from the PS1 mutant mice exhibited elevated basal intracellular $\mathrm{Ca}^{2+}$ concentrations, and a markedly increased calcium response to phytohemagglutinin.

Our findings in studies of lymphocytes from PS1 mutant knockin mice (M146V mutation) provide further evidence that PS1 mutations cause calcium signaling defects and altered cytokine signaling in lymphocytes. We observed a higher level of spontaneous lymphocyte apoptosis in the spleens of PS1 mutant mice as compared to wild-type control mice; a subpopulation of lymphocytes from the PS1 mutant mice exhibited a spontaneous elevation of the cytosolic $\mathrm{Ca}^{2}$ concentration and increased vulnerability to apoptosis induced by thapsigargin (SL 

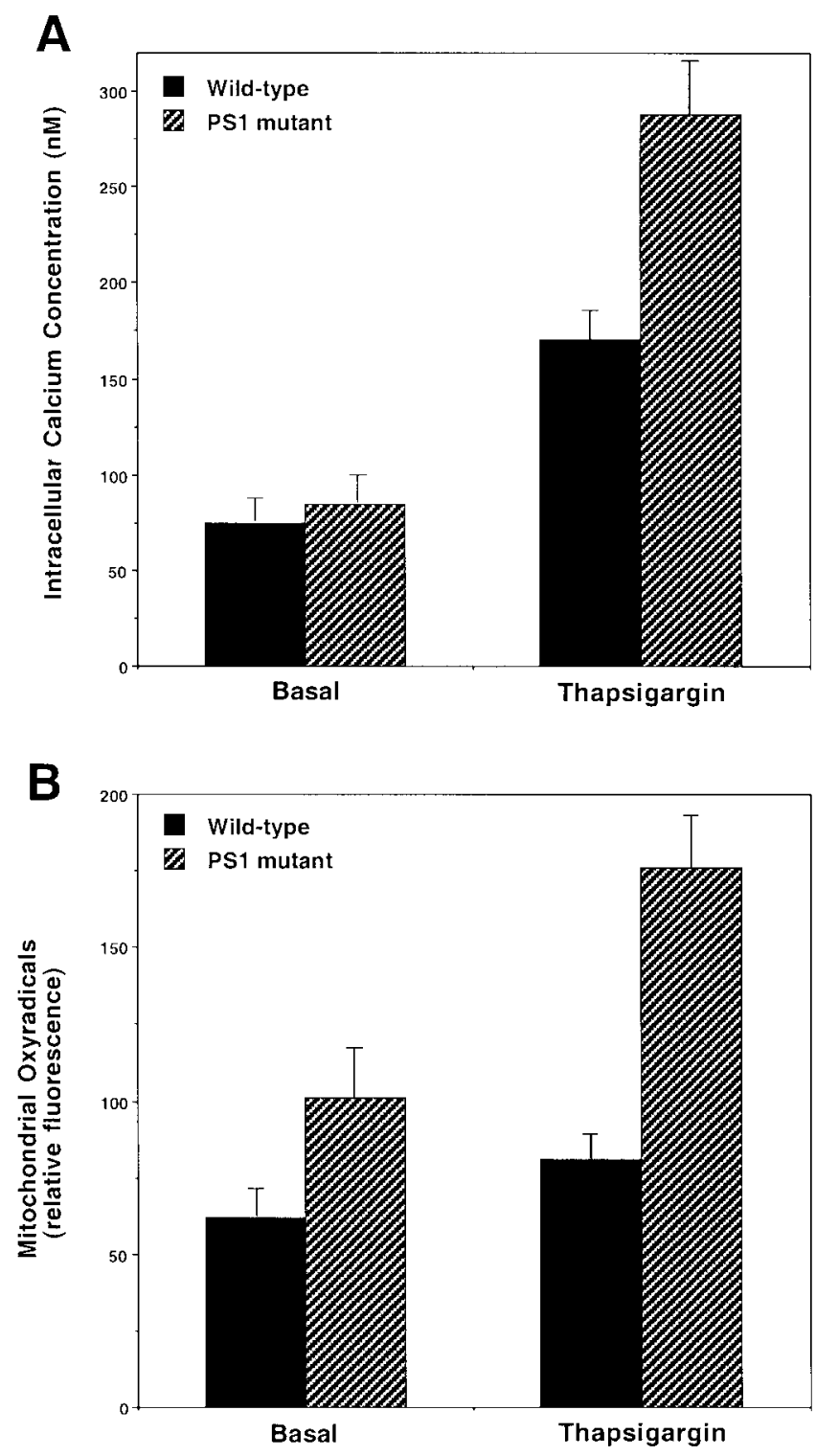

Figure 4

Chan and MP Mattson, unpublished data). In addition, lymphocytes from PS1 mutant mice that do not exhibit spontaneous apoptosis, nevertheless exhibit greatly enhanced calcium responses to thapsigargin (Figure 4A). In addition, isolated lymphocytes from PS1 mutant mice exhibit enhanced mitochondrial oxyradical production following exposure to thapsigargin (Figure 4B). The dysregulation of cellular calcium homeostasis and enhanced oxidative stress in lymphocytes from PS1 mutant mice is similar to the alterations observed in neurons from the same mice (Guo et al, 1999), suggesting a similar adverse effect of PS1 mutations in neurons and immune cells.

Interestingly, when challenged with LPS, PS1 mutant mice exhibit enhanced levels of proinflammatory cytokines in their brains (Lee et al, 2001; Table 1).
Table 1 Alterations in levels of cytokine mRNAs following an LPS challenge in the brain and spleen of PS1 mutant knockin mice

\begin{tabular}{llcc}
\hline & \multicolumn{2}{c}{ Response to LPS (compared to wild-type mice) } \\
\cline { 2 - 4 } Cytokine & Hippocampus & Cerebral cortex & Spleen \\
\hline IL-1alpha & Increased & Increased & No change \\
IL-1beta & Increased & Increased & No change \\
IL-1RA & Increased & Increased & No change \\
IL-6 & Increased & Increased & No change \\
TNF-alpha & Small increase & Increased & No change \\
Interferon- & No change & No change & Decreased \\
gamma & & & \\
\hline
\end{tabular}

Note. Levels of mRNAs for the indicated cytokines were quantified by ribonuclease protection assay analysis. Summary of data from Lee et al (2001).

In addition, T-cell receptor signaling appears to be impaired in lymphocytes from PS1 mutant mice, resulting in reduced IL-2 production (SL Chan and MP Mattson, unpublished data). The evidence that PS1 mutations cause alterations in immune function in mice that show no overt brain pathology suggests that altered immune function may occur independently from and/or precede the neurodegenerative process in $\mathrm{AD}$.

\section{Conclusions}

The findings described above suggest that alterations in the immune system may contribute to the pathogenesis of $\mathrm{AD}$. There is certainly an inflammatory component associated with amyloid deposition and the neurodegerative process in the brain. However, the immune system may normally play an important role in removing amyloid from the brain, as suggested by recent studies in which amyloid deposits were cleared from the brains of APP mutant mice following immunization with aggregated $\mathrm{A} \beta$ (Schenk et al, 1999). The latter findings suggest that a compromised immune response could promote amyloid deposition. Additional studies suggest that learning and memory deficits can be ameliorated in APP mutant mice by $\mathrm{A} \beta$ vaccination (Janus et al, 2000; Morgan et al, 2000). Peripheral consequences of a compromised immune system are may also contribute to the clinical course of $\mathrm{AD}$. $\mathrm{AD}$ patients exhibit increased susceptibility to infection, with pneumonia being the most common cause of death in patients with lateonset $\mathrm{AD}$, as well as in patients with familial earlyonset disease (Ueki et al, 2001). Goals for future studies include (1) elucidation of the specific molecular and cellular alterations of peripheral and central immune cells in AD; (2) establishing the links between transmissible and nontransmissible neurodegenerative disorders; and (3) the development of pharmacological and dietary interventions that may normalize immune function in viral and prion disorders and $\mathrm{AD}$. 


\section{References}

Artavanis-Tsakonis S, Matsuno K, Fortini ME (1995). Notch signaling. Science 268: 225-231.

Atwood CS, Huang X, Khatri A, Scarpa RC, Kim YS, Moir RD, Tanzi RE, Roher AE, Bush AI (2000). Copper catalyzed oxidation of Alzheimer Abeta. Cell Mol Biol 46: $777-783$

Baker HF, Ridley RM, Duchen LW, Crow TJ, Bruton CJ (1994). Induction of beta (A4)-amyloid in primates by injection of Alzheimer's disease brain homogenate. Comparison with transmission of spongiform encephalopathy. Mol Neurobiol 8: 25-39.

Barger SW, Basile AS (2001). Activation of microglia by secreted amyloid precursor protein evokes release of glutamate by cystine exchange and attenuates synaptic function. J Neurochem 76: 846-854.

Barger SW, Horster D, Furukawa K, Goodman Y, Krieglstein J, Mattson MP (1995). Tumor necrosis factors alpha and beta protect neurons against amyloid beta-peptide toxicity: evidence for involvement of a kappa B-binding factor and attenuation of peroxide and $\mathrm{Ca}^{2+}$ accumulation. Proc Natl Acad Sci USA 92: 9328-9332.

Barrow PA, Empson RM, Gladwell SJ, Anderson CM, Killick R, Yu X, Jefferys JG, Duff K (2000). Functional phenotype in transgenic mice expressing mutant human presenilin-1. Neurobiol Dis 7: 119-126.

Begley JG, Duan W, Chan S, Duff K, Mattson MP (1999). Altered calcium homeostasis and mitochondrial dysfunction in cortical synaptic compartments of presenilin-1 mutant mice. J Neurochem 72: 1030-1039.

Berridge MJ, Lipp P, Bootman MD (2000). The versatility and universality of calcium signaling, Nat Rev Mol Cell Biol 1: 11-21.

Blanc EM, Keller JN, Fernandez S, Mattson MP (1998). 4-Hydroxynonenal, a lipid peroxidation product, impairs glutamate transport in cortical astrocytes. Glia 22: 149-160.

Bongioanni P, Boccardi B, Borgna M, Castagna M, Mondino $C$ (1997). T-cell interferon gamma binding in patients with dementia of the Alzheimer type. Arch Neurol 54: 457-462.

Bongioanni P, Boccardi B, Borgna M, Rossi B (1998). Tlymphocyte interleukin 6 receptor binding in patients with dementia of Alzheimer type. Arch Neurol 55: 13051308.

Bourguignon LY, Jin H (1995). Identification of the ankyrinbinding domain of the mouse T-lymphoma cell inositol 1,4,5-trisphosphate (IP3) receptor and its role in the regulation of $\mathrm{IP}_{3}$-mediated internal $\mathrm{Ca}^{2+}$ release. J Biol Chem 270: 7257-7260.

Brillantes AM, Ondrias BK, Scott A, Kobrinsky E, Ondriasova E, Moschella MC, Jararaman T, Landers M, Ehrlich BE, Marks AR (1994). Stabilization of calcium release channel (ryanodine receptor) function by FK-506 binding protein. Cell 77: 513-523.

Bruce-Keller AJ, Umberger G, McFall R, Mattson MP (1999). Food restriction reduces brain damage and improves behavioral outcome following excitotoxic and metabolic insults. Ann Neurol 45: 8-15.

Bruunsgaard H, Andersen-Ranberg K, Jeune B, Pedersen AN, Skinhoj P, Pedersen BK (1999). A high plasma concentration of TNF-alpha is associated with dementia in centenarians. J Gerontol A Biol Sci Med Sci 54: M357M364.
Butterfield DA, Drake J, Pocernich C, Castegna A (2001). Evidence of oxidative damage in Alzheimer's disease brain: central role for amyloid beta-peptide. Trends Mol Med 7: 548-554.

Buxbaum JD, Choi EK, Luo Y, Lilliehook C, Crowley AC, Merriam DE, Wasco W (1998). Calsenilin: a calciumbinding protein that interacts with the presenilins and regulates the levels of a presenilin fragment. Nat Med 4: 1177-1181.

Cameron AM, Steiner JP, Roskams AJ, Ali SM, Ronnett GV, Snyder SH (1996). Calcineurin associated with the inositol 1,4,5-trisphosphate receptor-FKBP12 complex modulates $\mathrm{Ca}^{2+}$ flux. Cell 83: 463-472.

Cecchi C, Latorraca S, Sorbi S, Iantomasi T, Favilli F, Vincenzini MT, Liguri G (1999). Gluthatione level is altered in lymphoblasts from patients with familial Alzheimer's disease. Neurosci Lett 275: 152-154.

Chan SL, Mayne M, Holden CP, Geiger JD, Mattson MP (2000). Presenilin-1 mutations increase levels of ryanodine receptors and calcium release in PC12 cells and cortical neurons. J Biol Chem 275: 1819518200.

Chittajallu R, Alford S, Collingridge GL (1998). $\mathrm{Ca}^{2+}$ and synaptic plasticity. Cell Calcium 24: 377-385.

Conlon RA, Reaume AG, Rossant J (1995). Notch1 is required for the coordinate segmentation of somites. Development 121: 1533-1542.

Cruz-Sanchez F, Lafuente J, Figols J, Cervos-Navarro J (1988). Topographic analysis of neuropathologic findings in 16 cases of Creutzfeldt-Jacob disease. Arch Neurobiol (Madr) 51: 191-196.

Culmsee C, Zhu Z, Yu QS, Chan SL, Camandola S, Guo Z, Greig N, Mattson MP (2001). A synthetic inhibitor of p53 protects neurons against death induced by ischemic and excitotoxic insults, and amyloid $\beta$-peptide. $J \mathrm{Neu}$ rochem 77: 220-228.

D’Adamio L, Lacana E, Vito P (1997). Functional cloning of genes involved in T-cell receptor-induced programmed cell death. Semin Immunol 9: 17-23.

DiCarlo G, Wilcock D, Henderson D, Gordon M, Morgan $\mathrm{D}$ (2001). Intrahippocampal LPS injections reduce $\mathrm{A} \beta$ load in APP+PS1 transgenic mice. Neurobiol Aging 22: 1007-1012.

Duan W, Mattson MP (1999). Dietary restriction and 2-deoxyglucose administration improve behavioral outcome and reduce degeneration of dopaminergic neurons in models of Parkinson's disease. J Neurosci Res 57: 195206.

Eckert A, Forstl H, Zerfass R, Hartmann H, Muller WE (1996). Lymphocytes and neutrophils as peripheral models to study the effect of beta-amyloid on cellular calcium signalling in Alzheimer's disease. Life Sci 59: 499-510.

Eckert A, Schindowski K, Leutner S, Luckhaus C, Touchet N, Czech C, Muller WE (2001). Alzheimer's disease-like alterations in peripheral cells from presenilin-1 transgenic mice. Neurobiol Dis 8: 331-342.

Evans DA, Hebert LE, Beckett LA, Scherr PA, Albert MS, Chown MJ, Pilgrim DM, Taylor JO (1997). Education and other measures of socioeconomic status and risk of incident Alzheimer disease in a defined population of older persons. Arch Neurol 54: 1399-1405.

Fazakerley JK, Allsopp TE (2001). Programmed cell death in virus infections of the nervous system. Curr Top Microbiol Immunol 253: 95-119. 
Flescher E, Ledbetter JA, Schieven GL, Vela-Roch N, Fossum D, Dang H, Ogawa N, Talal N (1994). Longitudinal exposure of human T lymphocytes to weak oxidative stress suppresses transmembrane and nuclear signal transduction. J Immunol 153: 4880-4889.

Galasko D, Hansen LA, Katzman R, Wiederholt W, Masliah E, Terry R, Hill LR, Lessin P, Thal LJ (1994). Clinical-neuropathological correlations in Alzheimer's disease and related dementias. Arch Neurol 51: 888895.

Giese A, Kretzschmar HA (2001). Prion-induced neuronal damage-the mechanisms of neuronal destruction in the subacute spongiform encephalopathies. Curr Top Microbiol Immunol 253: 203-217.

Grossmann A, Kukull WA, Jinneman JC, Bird TD, Villacres EC, Larson EB, Rabinovitch PS (1993). Intracellular calcium response is reduced in CD4+ lymphocytes in Alzheimer's disease and in older persons with Down's syndrome. Neurobiol Aging 14: 177-185.

Guo Q, Christakos S, Robinson N, Mattson MP (1998a). Calbindin D28k blocks the proapoptotic actions of mutant presenilin 1: reduced oxidative stress and preserved mitochondrial function. Proc Natl Acad Sci USA 95: 32273232.

Guo Q, Fu W, Sopher BL, Miller MW, Ware CB, Martin GM, Mattson MP (1999). Increased vulnerability of hippocampal neurons to excitotoxic necrosis in presenilin-1 mutant knockin mice. Nat Med 5: 101-107.

Guo Q, Furukawa K, Sopher BL, Pham DG, Robinson N, Martin GM, Mattson MP (1996). Alzheimer's PS-1 mutation perturbs calcium homeostasis and sensitizes PC12 cells to death induced by amyloid $\beta$-peptide. NeuroReport 8: 379-383.

Guo Q, Robinson N, Mattson MP (1998b). Secreted betaamyloid precursor protein counteracts the proapoptotic action of mutant presenilin-1 by activation of NF- $\kappa \mathrm{B}$ and stabilization of calcium homeostasis. J Biol Chem 273: 12341-12351.

Guo Q, Sopher BL, Pham DG, Furukawa K, Robinson N, Martin GM, Mattson MP (1997). Alzheimer's presenilin mutation sensitizes neural cells to apoptosis induced by trophic factor withdrawal and amyloid $\beta$-peptide. J Neurosci 17: 4212-4222.

Guse AH (1998). $\mathrm{Ca}^{2+}$ signaling in T-lymphocytes. Crit Rev Immunol 18: 419-448.

Handler M, Yang X, Shen J (2000). Presenilin-1 regulates neuronal differentiation during neurogenesis. Development 127: 2593-2606.

Hardy J (1997). Amyloid, the presenilins and Alzheimer's disease. Trends Neurosci 20: 154-159.

Ibarreta D, Parrilla R, Ayuso MS (1997). Altered $\mathrm{Ca}^{2+}$ homeostasis in lymphoblasts from patients with late onset Alzheimer disease. Alzheimer Dis Assoc Disord 11: 220227.

Ibarreta D, Urcelay E, Parrilla R, Ayuso MS (1998). Distinct $\mathrm{pH}$ homeostatic features in lymphoblasts from Alzheimer's disease patients. Ann Neurol 44: 216222.

Janus C, Pearson J, McLaurin J, Mathews PM, Jiang Y, Schmidt SD, Chishti MA, Horne P, Heslin D, French J, Mount HT, Nixon RA, Mercken M, Bergeron C, Fraser PE, St George-Hyslop P, Westaway D (2000). A beta peptide immunization reduces behavioural impairment and plaques in a model of Alzheimer's disease. Nature 408: 979-982.
Karlsson JO, Blennow K, Janson I, Blomgren K, Karlsson I, Regland B, Wallin A, Gottfries CG (1995). Increased proteolytic activity in lymphocytes from patients with early onset Alzheimer's disease. Neurobiol Aging 16: 901-906.

Khan AA, Soloski MJ, Sharp AH, Schilling G, Sabatini DM, Li SH, Ross CA, Snyder SH (1996). Lymphocyte apoptosis: mediation by increased type 3 inositol 1,4,5trisphosphate receptor. Science 273: 503-507.

Kim WK, Ko KH (1998). Potentiation of $N$-methyl-Daspartate-mediated neurotoxicity by immunostimulated murine microglia. J Neurosci Res 54: 17-26.

Kruman II, Nath A, Mattson MP (1998). HIV-1 protein Tat induces apoptosis of hippocampal neurons by a mechanism involving caspase activation, calcium overload, and oxidative stress. Exp Neurol 154: 276288.

Lanzrein AS, Johnston CM, Perry VH, Jobst KA, King EM, Smith AD (1998). Longitudinal study of inflammatory factors in serum, cerebrospinal fluid, and brain tissue in Alzheimer disease: interleukin-1beta, interleukin-6, interleukin-1 receptor antagonist, tumor necrosis factoralpha, the soluble tumor necrosis factor receptors I and II, and alpha1-antichymotrypsin. Alzheimer Dis Assoc Disord 12: 215-227.

Lee J, Chan SL, Taub DH, Camandola S, Mattson MP (2001). Induction of inflammatory cytokines is potentiated in the brains of presenilin-1 mutant knock-in mice. Soc Neurosci Abstr 27: Program number 860.4.

Lee J, Duan W, Long JM, Ingram DK, Mattson MP (2000). Dietary restriction increases survival of newly-generated neural cells and induces BDNF expression in the dentate gyrus of rats. J Mol Neurosci 15: 99-108.

Lee J, Seroogy KB, Mattson MP (2002). Dietary restriction enhances neurotrophin production and neurogenesis in the hippocampus of adult mice. J Neurochem 80: 539547.

Leissring MA, Akbari Y, Fanger CM, Cahalan MD, Mattson MP, LaFerla FM (2000a). Capacitative calcium entry deficits and elevated luminal calcium content in mutant presenilin-1 knockin mice. J Cell Biol 149: 793798.

Leissring MA, Yamasaki TR, Wasco W, Buxbaum JD, Parker I, LaFerla FM (2000b). Calsenilin reverses presenilinmediated enhancement of calcium signaling. Proc Natl Acad Sci USA 97: 8590-8593.

Lewis RS (2001). Calcium signaling mechanisms in T lymphocytes. Annu Rev Immunol 19: 497-521.

Licastro F, Pedrini S, Caputo L, Annoni G, Davis LJ, Ferri C, Casadei V, Grimaldi LM (2000). Increased plasma levels of interleukin-1, interleukin-6 and alpha1-antichymotrypsin in patients with Alzheimer's disease: peripheral inflammation or signals from the brain? J Neuroimmunol 103: 97-102.

Lipton SA (1998). Neuronal injury associated with HIV-1: approaches to treatment. Annu Rev Pharmacol Toxicol 38: 159-177.

Lombardi VR, Garcia M, Rey L, Cacabelos R (1999). Characterization of cytokine production, screening of lymphocyte subset patterns and in vitro apoptosis in healthy and Alzheimer's Disease (AD) individuals. J Neuroimmunol 97: 163-171.

Lukiw WJ, Bazan NG (2000). Neuroinflammatory signaling upregulation in Alzheimer's disease. Neurochem Res 25: 1173-1184. 
Lye TC, Shores EA (2000). Traumatic brain injury as a risk factor for Alzheimer's disease: a review. Neuropsychol Rev 10: 115-129.

Mark RJ, Hensley K, Butterfield DA, Mattson MP (1995). Amyloid $\beta$-peptide impairs ion-motive ATPase activities: evidence for a role in loss of neuronal $\mathrm{Ca}^{2+}$ homeostasis and cell death. J Neurosci 15: 62396249.

Mark RJ, Pang Z, Geddes JW, Mattson MP (1997). Amyloid $\beta$-peptide impairs glucose uptake in hippocampal and cortical neurons: involvement of membrane lipid peroxidation. J Neurosci 17: 1046-1054.

Maruyama K, Usami M, Kametani F, Tomita T, Iwatsubo T, Saido TC, Mori H, Ishiura S (2000). Molecular interactions between presenilin and calpain: inhibition of $\mathrm{m}-$ calpain protease activity by presenilin-1, -2 and cleavage of presenilin-1 by m-, mu-calpain. Int J Mol Med 5: 269-273.

Masters CL, Beyreuther K (1988). Neuropathology of unconventional virus infections: molecular pathology of spongiform change and amyloid plaque deposition. Ciba Found Symp 135: 24-36.

Mattson MP (1990). Antigenic changes similar to those seen in neurofibrillary tangles are elicited by glutamate and $\mathrm{Ca}^{2+}$ influx in cultured hippocampal neurons. Neuron 4: 105-117.

Mattson MP (1997). Cellular actions of $\beta$-amyloid precursor protein and its soluble and fibrillogenic derivatives. Physiol Rev 77: 1081-1132.

Mattson MP (2000). Apoptosis in neurodegenerative disorders. Nat Rev Mol Cell Biol 1: 120-129.

Mattson MP, Begley JG, Mark RJ, Furukawa K (1997b). Abeta25-35 induces rapid lysis of red blood cells: contrast with Abeta1-42 and examination of underlying mechanisms. Brain Res 771: 147-153.

Mattson MP, Cheng B, Culwell AR, Esch FS, Lieberburg I, Rydel RE (1993). Evidence for excitoprotective and intraneuronal calcium-regulating roles for secreted forms of the beta-amyloid precursor protein. Neuron 10: 243254.

Mattson MP, Goodman Y, Luo H, Fu W, Furukawa K (1997). Activation of NF-kappaB protects hippocampal neurons against oxidative stress-induced apoptosis: evidence for induction of manganese superoxide dismutase and suppression of peroxynitrite production and protein tyrosine nitration. J Neurosci Res 49: 681-697.

Mayeux R, Costa R, Bell K, Merchant C, Tung MX, Jacobs D (1999). Reduced risk of Alzheimer's disease among individuals with low calorie intake. Neurology 59: S296S297.

McGeer EG, McGeer PL (1999). Brain inflammation in Alzheimer disease and the therapeutic implications. Curr Pharm Des 5: 821-836.

Mecocci P, Polidori MC, Ingegni T, Cherubini A, Chionne F, Cecchetti R, Senin U (1998). Oxidative damage to DNA in lymphocytes from AD patients. Neurology 51: 10141017.

Morgan D, Diamond DM, Gottschall PE, Ugen KE, Dickey C, Hardy J, Duff K, Jantzen P, DiCarlo G, Wilcock D, Connor K, Hatcher J, Hope C, Gordon M, Arendash GW (2000). A beta peptide vaccination prevents memory loss in an animal model of Alzheimer's disease. Nature 408: 982985.

Morocz M, Kalman J, Juhasz A, Sinko I, McGlynn AP, Downes CS, Janka Z, Rasko I (2002). Elevated levels of oxidative DNA damage in lymphocytes from pa- tients with Alzheimer's disease. Neurobiol Aging 23: 47-53.

Mrak RE, Griffin WS (2001). Interleukin-1, neuroinflammation, and Alzheimer's disease. Neurobiol Aging 22: 903908.

Nath A (1999). Pathobiology of human immunodeficiency virus dementia. Semin Neurol 19: 113-127.

Osborne B, Miele L (1999). Notch and the immune system. Immunity 11: 653-663.

Pack-Chung E, Meyers MB, Pettingell WP, Moir RD, Brownawell AM, Cheng I, Tanzi RE, Kim TW (2000). Presenilin 2 interacts with sorcin, a modulator of the ryanodine receptor. J Biol Chem 275: 14440-14445.

Papassotiropoulos A, Bagli M, Jessen F, Bayer TA, Maier W, Rao ML, Heun R (1999). A genetic variation of the inflammatory cytokine interleukin-6 delays the initial onset and reduces the risk for sporadic Alzheimer's disease. Ann Neurol 45: 666-668.

Parent A, Linden DJ, Sisodia SS, Borchelt DR (1999). Synaptic transmission and hippocampal long-term potentiation in transgenic mice expressing FAD-linked presenilin 1. Neurobiol Dis 6: 56-62.

Pickel VM, Clarke CL, Meyers MB (1997). Ultrastructural localization of sorcin, a $22 \mathrm{kDa}$ calcium binding protein, in the rat caudate-putamen nucleus: association with ryanodine receptors and intracellular calcium release. J Comp Neurol 386: 625-634.

Prusiner SB (2001). Shattuck lecture-neurodegenerative diseases and prions. N Engl J Med 344: 1516-1526.

Rausch DM, Davis MR (2001). HIV in the CNS: pathogenic relationships to systemic HIV disease and other CNS diseases. J NeuroVirol 7: 85-96.

Rogers J, Cooper NR, Webster S, Schultz J, McGeer PL, Styren SD, Civin WH, Brachova L, Bradt B, Ward P, Lieberburg I (1992). Complement activation by betaamyloid in Alzheimer disease. Proc Natl Acad Sci USA 89: 10016-10020.

Schenk D, Barbour R, Dunn W, Gordon G, Grajeda H, Guido T, Hu K, Huang J, Johnson-Wood K, Khan K, Kholodenko D, Lee M, Liao Z, Lieberburg I, Motter R, Mutter L, Soriano F, Shopp G, Vasquez N, Vandevert C, Walker S, Wogulis M, Yednock T, Games D, Seubert P (1999). Immunization with amyloid-beta attenuates Alzheimerdisease-like pathology in the PDAPP mouse. Nature 400: 173-177.

Shalit F, Sredni B, Brodie C, Kott E, Huberman M (1995). $\mathrm{T}$ lymphocyte subpopulations and activation markers correlate with severity of Alzheimer's disease. Clin Immunol Immunopathol 75: 246-250.

Shen J, Bronson RT, Chen DF, Xia W, Selkoe DJ, Tonegawa $S$ (1997). Skeletal and CNS defects in presenilin-1deficient mice. Cell 89: 629-639.

Solerte SB, Fioravanti M, Pascale A, Ferrari E, Govoni $\mathrm{S}$, Battaini F (1998). Increased natural killer cell cytotoxicity in Alzheimer's disease may involve protein kinase C dysregulation. Neurobiol Aging 19: 191199.

Song C, Vandewoude M, Stevens W, De Clerck L, Van der Planken M, Whelan A, Anisman H, Dossche A, Maes M (1999). Alterations in immune functions during normal aging and Alzheimer's disease. Psychiatry Res 85: 7180.

Stabler SM, Ostrowski LL, Janicki SM, Monteiro MJ (1999). A myristoylated calcium-binding protein that preferentially interacts with the Alzheimer's disease presenilin 2 protein. J Cell Biol 145: 1277-1292. 
Struhl G, Greenwald I (2001). Presenilin-mediated transmembrane cleavage is required for Notch signal transduction in Drosophila. Proc Natl Acad Sci USA 98: 229234.

Sulger J, Dumais-Huber C, Zerfass R, Henn FA, Aldenhoff JB (1999). The calcium response of human T lymphocytes is decreased in aging but increased in Alzheimer's dementia. Biol Psychiatry 45: 737-742.

Takahashi H, Mercken M, Honda T, Saito Y, Murayama M, Song S, Takashima A (1999). Impaired proteolytic processing of presenilin-1 in chromosome 14-linked familial Alzheimer's disease patient lymphocytes. Neurosci Lett 260: 121-124.

Ueki A, Shinjo H, Shimode H, Nakajima T, Morita Y (2001). Factors associated with mortality in patients with early-onset Alzheimer's disease: a five-year longitudinal study. Int $J$ Geriatr Psychiatry 16: 810815.

Vassar R, Bennett BD, Babu-Khan S, Kahn S, Mendiaz EA, Denis P, Teplow DB, Ross S, Amarante P, Loeloff R, Luo Y, Fisher S, Fuller J, Edenson S, Lile J, Jarosinski MA, Biere AL, Curran E, Burgess T, Louis JC, Collins F, Treanor J, Rogers G, Citron M (1999). Beta-secretase cleavage of Alzheimer's amyloid precursor protein by the transmembrane aspartic protease BACE. Science 286: $735-741$.
Webster S, Glabe C, Rogers J (1995). Multivalent binding of complement protein C1Q to the amyloid beta-peptide (A beta) promotes the nucleation phase of A beta aggregation. Biochem Biophys Res Commun 217: 869-875.

Williams R, Lendahl U, Lardelli M (1995). Complementary and combinatorial patterns of Notch gene family expression during early mouse development. Mech Dev 53: 357-368.

Yamada M, Miyawaki A, Saito K, Nakajima T, YamamotoHino M, Ryo Y, Furuichi T, Mikoshiba K (1995). The calmodulin-binding domain in the mouse type 1 inositol 1,4,5-trisphosphate receptor. Biochem J 308: 83-88.

Yasojima K, Schwab C, McGeer EG, McGeer PL (2000). Human neurons generate C-reactive protein and amyloid P: upregulation in Alzheimer's disease. Brain Res 887: 80-89.

Yoo AS, Cheng I, Chung S, Grenfell TZ, Lee H, Pack-Chung E, Handler M, Shen J, Xia W, Tesco G, Saunders AJ, Ding K, Frosch MP, RE, Kim TW (2000). Presenilinmediated modulation of capacitative calcium entry. Neuron 27: 561-572.

$\mathrm{Yu} \mathrm{ZF}$, Mattson MP (1999). Dietary restriction and 2deoxyglucose administration reduce focal ischemic brain damage and improve behavioral outcome: evidence for a preconditioning mechanism. J Neurosci Res 57: 830-839. 